\title{
TATA NIAGA ROTAN DI KATINGAN
}

\section{RATTAN'S TRADE SYSTEM IN KATINGAN}

\author{
Septi Dhanik Prastiwi \\ Balai Pelestarian Nilai Budaya Kalimantan Barat \\ Jl. Letjen Sutoyo Pontianak \\ Telp. (0561) 737906 Fax (0561) 760707 \\ Pos-El : septi.dhanik@gmail.com
}

Diterima 18 September 2017

Disetujui tanggal 17 November 2017

\begin{abstract}
The unstable price on rattan turn to be the problem that should be faced ny rattan farmers. They must accept the price that have been determined by the rattan's market. It is interesting to find out how the socio-economic life of rattan farmers. Therefore the issues to be discussed are (1) How is the rattan trade sistem in the countryside? (2) How does the adaption conducted by rattan farmers to face the unstable price of rattan? This research conducted in Talingke village, Tasik Payawan, Katingan regency. Data was collected with 3 techniques : study of literature, observation and interview. From this research, there are two to three actors who involved in the rattan trading system: rattan farmer, pemberi panjar and capital owners. The three actors formed reciprocity and patron-client relationships. The dominance of capital owners in determining the prices faced by rattan farmers by looking for other alternative livelihoods. The strategy which is used utilizing the natural resources (fish, timber and minerals) at the surrounding as an income source.
\end{abstract}

Keywords: rattan, trading system, price fluctuation, and adaptation strategy.

\begin{abstract}
ABSTRAK
Harga rotan yang tidak stabil merupakan permasalahan yang dihadapi oleh para petani rotan. Mereka harus menerima harga yang telah ditetapkan oleh pasar. Untuk mengetahui bagaimana kehidupan social ekonomi petani rotan di Katingan, maka permasalahan yang akan dibahas yaitu (1) Bagaimana sistem penjualan rotan di desa? (2) Bagaimana strategi adaptasi yang dilakukan oleh petani rotan menghadapi fluktuasi harga rotan? Penelusuran permasalahan ini dilakukan di desa Talingke, Kecamatan Tasik Payawan, Kabupaten Katingan Provinsi Kalimantan Tengah. Pengumpulan data dilakukan dilokasi tersebut melalui tiga teknik yaitu studi pustaka, observasi dan wawancara. Dari hasil penelitian diperoleh data bahwa dalam sistem penjualan rotan di desa, terdapat dua hingga tiga pelaku utama yaitu petani rotan, pemberi panjar dan pemilik modal (pengepul). Ketiga pelaku tersebut membentuk hubungan resiprositas dan sekaligus patron-klien. Dominasi pemilik modal dalam menentukan harga dihadapi petani rotan dengan mencari alternative mata pencaharian lain. Strategi yang dilakukan yaitu dengan memanfaatkan sumber daya alam yang ada di sekitarnya sebagai sumber penghasilan.
\end{abstract}

Kata kunci : rotan, tata niaga, fluktuasi harga, dan strategi adaptasi. 


\section{A. PENDAHULUAN}

Rotan merupakan salah satu sumber daya alam yang sangat potensial di Kabupaten Katingan, Provinsi Kalimantan. Menurut data Dinas Kehutanan Kabupaten Katingan tahun 2006, lahan rotan di Katingan seluas 325.000 ha mampu menghasilkan rotan basah 99,4 ton per tahun (WWF, 2013:1). Sementara data dari Teropong dan Yayasan SHK Kaltim pada tahun 2005 disebutkan bahwa dari 11.430 hektar rotan di Katingan berpotensi menghasilkan 11.430 ton rotan basah, atau 5.715 ton rotan kering (Sumardjani, 2011:23). Dari varian rotan, berdasarkan eksplorasi yang dilakukan WWF, kekayaan rotan di Katingan tidak hanya dari kuantitas rotan namun juga dari jenis rotan yang ada. Dari data WWF ditemukan 41 jenis rotan yang berhasil diidentifikasi di beberapa wilayah di Katingan. Namun diantara ke 41 jenis tersebut, hanya ada 2 jenis rotan yang dibudidayakan masyarakat yaitu rotan Irit/ taman (Calamus trachycoleus) dan rotan Sigi/ Sega (Calamus caesius ${ }^{1}$ ) (WWF, 2013:15).

Rotan merupakan sumber daya alam hayati yang sangat potensial dan tanaman ini telah menjadi bagian dari kehidupan masyarakat Dayak. Penanaman rotan telah dilakukan masyarakat Dayak sejak ratusan tahun lalu dan merupakan salah satu sistem agroforestry tertua di Indonesia bersamaan dengan system agroforestry di daerah lain di Indonesia (Sumardjani, 2011:24). Bagi masyarakat Dayak, tanaman rotan dapat dimanfaatkan sebagai sarana pengobatan, bahan makanan (umbut rotan), bahan bangunan (penyambung kayu/pengikat), bahan untuk perkakas rumah tangga (keranjang, dll), dan bahkan dapat digunakan sebagai

1 Rotan irit dan sigi memiliki kualitas batang yang baik sehingga memiliki nilai ekonomi yang tinggi dibandingkan dengan jenis lain. Selain itu kedua jenis rotan ini juga memiliki karakter yang baik seperti batang berumpun, pertumbuhan cepat, daya adaptasi tinggi dan mudah dipelihara. klaim kepemilikan suatu lahan². Selain bermanfaat dalam kehidupan sehari-hari, rotan juga memiliki fungsi yang sangat penting yaitu sebagai sumber penghasilan masyarakat. Hampir $50 \%$ penduduk yang tinggal di sekitar hutan bermata pencaharian sebagai petani rotan dan memiliki lahan yang relative terjaga keamanan dan kelestariannya (WWF, 2013:1).

Dengan potensi rotan yang cukup besar, Katingan bisa disebut sebagai sentra produksi rotan Kalimantan Tengah. Di bawah kepemimpinan Bupati Duwel Rawing (periode 2008-2013), kabupaten Katingan memproklamirkan diri sebagai kabupaten rotan dengan menetapkan visi Kabupaten Katingan sebagai pusat produksi dan perdagangan rotan Indonesia. Dalam laman kpshk. org, pada tahun 2010 diberitakan bahwa keseriusan pemerintah Katingan dalam mewujudkan visi tersebut dilakukan dengan memberikan subsidi pembelian rotan basah masyarakat Rp 2.000 per kg. Selain itu, untuk menyiapkan SDM yang diharapkan dapat mengelola potensi rotan di Katingan telah didirikan SMK rotan.

Pemerintah Kabupaten Katingan juga mendapat dukungan dari beberapa pihak seperti Bank Indonesia yang memberikan dukungan pembinaan kelompok pengrajin rotan, dibangunnya kerjasama dengan Credit Union yang diharapkan bisa menjadi mitra dalam memberikan modal kepada petani, dan berdirinya PD Katingan Jaya yang akan menampung hasil rotan dari petani dan pengrajin. Selain itu upaya untuk menciptakan Katingan sebagai sentra produksi sekaligus sentra pasar kerajinan rotan juga dilakukan dengan menggalang pola kemitraan, peningkatan produk unggulan, peningkatan wirausaha di sektor rotan dan

2 Tanaman rotan digunakan sebagai penanda untuk penguasaan suatu lahan/wilayah sehingga jika ingin menggunakan lahan yang ada tanaman rotannya maka harus ditelusuri siapa pemilik lahan tersebut. 
juga dilakukannya MoU dengan Cirebon ${ }^{3}$ selaku konsumen rotan dari Katingan.

Segala upaya yang telah dilakukan pemerintah daerah ternyata masih belum bisa mewujudkan Katingan sebagai kabupaten rotan. Kebijakan yang telah dibuat pemerintah daerah pada kenyataannya belum menyentuh kehidupan para petani rotan secara langsung. Dari waktu ke waktu petani rotan terus dihadapkan pada satu masalah yang sama. Saat harga rotan tinggi, petani mendapatkan cukup penghasilan untuk memenuhi kebutuhan hidupnya. Namun ketika harga rotan rendah, petani rotan tidak bisa melakukan apa-apa selain tunduk pada mekanisme harga pasar. Para petani tidak berdaya karena mekanisme harga rotan bergantung sepenuhnya kepada para pengepul yang membeli hasil panen rotan mereka. Petani hanya dihadapkan pada dua pilihan yaitu menjual hasil rotan dengan harga yang ditetapkan pengepul atau membiarkan tanaman rotan tetap berada di kebun. Di medio tahun 2000 an harga rotan $R p 200.000$ - Rp 220.000 per pikul terus mengalami penurunan hingga Rp 80.000 per pikul $l^{4}$ i tahun 2011. Hingga tahun 2017 harga rotan tetap tidak beranjak naik. Harga rotan yang tidak kunjung membaik akhirnya mendorong petani rotan untuk tidak lagi memanen rotannya. Sistem penjualan rotan, kebijakan pemerintah yang dirasakan tidak memihak menjadikan kehidupan petani rotan bertolak belakang dengan besarnya potensi rotan di kabupaten Katingan.

Berdasarkan latar belakang tersebut maka permasalahan yang perlu dikaji adalah :

1. Bagaimana sistem penjualan rotan di desa?

2. Bagaimana strategi adaptasi yang dilakukan petani rotan menghadapi fluktuasi harga rotan?

3 Cirebon dikenal sebagai sentra kerajinan rotan terbesar di Indonesia bahkan rotan Cirebon mampu menguasai $90 \%$ pasar rotan dunia (diakses dari www.disparbud.jabarprov. go.id).

41 Pikul setara dengan ukuran 1 kuintal.
Berdasarkan permasalahan tersebut, tujuan yang ingin dicapai dalam tulisan ini adalah:

1. Untuk mengetahui sistem penjualan rotan di desa

2. Untuk mengetahui strategi adaptasi yang dilakukan petani rotan menghadapi fluktuasi harga rotan.

Rotan merupakan salah satu sumber daya alam hasil hutan nonkayu dan termasuk dalam anggota suku palem-paleman (Arecaceae/Palmae). Berdasarkan ciri morfologinya rotan memiliki bagian-bagian tubuh yang sangat spesifik dan berbeda dengan jenis palem lainnya seperti kulit buah yang bersisik seperti buah salak, upih daun, tangkai dan tulang daun berduri serta batang merambat (WWF, 2013:5). Rotan dalam tulisan ini bukan merupakan hasil hutan yang tumbuh secara alami namun merupakan rotan hasil budidaya di lahan/ kebun masyarakat. Tulisan ini membahas kehidupan sosial ekonomi petani rotan yang ada di desa Talingke, Kecamatan Tasik Payawan, Kabupaten Katingan, provinsi Kalimantan Tengah dengan melihat tata niaga ${ }^{5}$ rotan ditingkat desa. Desa Talingke dipilih sebagai lokasi penelitian karena menjadi desa terdampak akibat dari rendahnya harga rotan yang saat ini mencapai titik terendah.

Rotan - sebagai salah satu sumber daya yang menjanjikan - selalu menarik untuk dikaji namun selama ini pembahasan mengenai rotan lebih banyak dilakukan pada pengelolaan industri rotan di hilir seperti yang dilakukan oleh Nangoy (2011) yang membahas mengenai industri rotan Cirebon yang terpuruk akibat kebijakan pemerintah pada tahun 2005 yang membuka kran ekspor rotan sehingga menjadikan harga bahan baku rotan di tingkat local mengalami ke-

5 Tata niaga menurut Kamus Besar Bahasa Indonesia diartikan sebagai sistem perdagangan komoditas tertentu. 
naikan. Tidak berbeda jauh dengan permasalahan tersebut, Dwi Wahyono (2013) juga membahas mengenai permasalahanpermasalahan yang dihadapi oleh industri yang berproduksi menggunakan bahan baku rotan di Jawa Timur. Sementara Eskak (2014) dan Pribadi (2012) mengkaji mengenai potensi rotan Sumbawa yang belum terkelola dengan baik dan upaya optimalisasi industri rotan di Palu. Di bumi Kalimantan, Susilawati (2014) membahas bagaimana posisi industri kecil dalam struktur industri rotan di Kota Banjarmasin dan Banjarbaru.

Di bagian hulu, beberapa kajian memang telah dilakukan namun tidak sebanyak pembahasan di bagian hilir seperti yang dilakukan oleh Erviyani (2017) yang membahas mengenai saluran tata niaga rotan di tingkat petani-pengumpul-pedagang besar dan fungsinya di Kabupaten Sidenreng Rappang. Masih di sector hulu pengelolaan rotan, Johanna Maria dkk (2015) membahas mengenai pola tanam dan pengolahan rotan secara tradisional serta tingkat sosial ekonomi petani rotan di Kabupaten Barito Selatan. Sementara Hidayat dkk (2006) membahas pola dan aspek pemungutan rotan pada dua kelompok pemungut yaitu masyarakat biasa dan masyarakat adat/Kubu atau suku Kubu. Semua kajian mengenai petani rotan tersebut belum membahas secara detail bagaimana system penjualan rotan yang dilakukan oleh petani dan permasalahan yang dihadapi. Perhatian terhadap pengembangan rotan baik oleh akademisi maupun pemerintah hampir selalu dilakukan pada sector hilir sementara kebijakan pemerintah terhadap pengelolaan rotan justru berdampak langsung kepada para petani rotan.

Pengumpulan data dilakukan dengan menggunakan tiga teknik yaitu studi pustaka, wawancara dan observasi. Studi pustaka dilakukan dalam dua tahap. Pertama studi pustaka yang dilakukan sebelum penelitian. Pada tahap ini studi pustaka dilakukan untuk melihat kajian-kajian mengenai rotan yang pernah dibahas oleh peneliti lain. Hasil dari studi pustaka ini dijadikan dasar bagi penulis untuk menempatkan di mana posisi kajian yang akan dilakukan. Studi pustaka tahap kedua dilakukan sesudah penelitian dengan tujuan mendapatkan bahan penulisan untuk memperkuat analisis data. Teknik pengumpulan data yang kedua yaitu observasi. Spradley dalam Sugiyono (2009 :229230) menyatakan bahwa objek penelitian yang diobservasi disebut dengan situasi sosial yang terdiri dari tiga komponen yaitu place (tempat), actor (pelaku) dan activities (aktivitas).

Observasi dilakukan pada ketiga komponen tersebut yang meliputi lahan rotan, petani rotan sebagai pelaku ekonomi serta aktivitas yang dilakukan. Pengamatan ini bertujuan untuk mengumpulkan keterangan dan sekaligus untuk melihat ada tidaknya keserasian antara tindakan yang dilakukan oleh informan dengan apa yang dikatakannya.

Teknik pengumpulan data yang ketiga adalah wawancara yang dilakukan kepada petani dan pengumpul rotan serta aparat pemerintah yang selama ini terlibat dalam pengelolaan rotan. Dalam wawancara, pemilihan informan dilakukan dengan teknik snowball yaitu dengan menggunakan saran dari informan yang telah diwawancarai di awal penelitian. Agar wawancara lebih terarah maka digunakan pedoman wawancara yang berbentuk pertanyaan terbuka sehingga memungkinkan adanya pengembangan-pengembangan pertanyaan sesuai kondisi di lapangan sebagai antisipasi bila terdapat informasi baru yang perlu didalami. Langkah selanjutnya setelah pengumpulan data, dilakukan analisis data. Analisis data adalah proses mengatur urutan data, mengorganisasikannya ke dalam suatu pola, kategori dan satuan uraian dasar (Patton dalam Moleong, 1996:103). Dalam proses ini data yang telah dikumpulkan baik berupa hasil wawancara, catatan pengamatan, doku- 
men, maupun foto ditelaah. Langkah berikutnya yaitu membuat rangkuman pernyataanpernyataan penting yang akan digunakan dalam penulisan. Data yang telah dirangkum kemudian dikelompokkan sesuai sistematika yang telah disusun. Sebagai langkah terakhir dilakukan penafsiran dan penarikan kesimpulan dengan didukung oleh studi literatur untuk memperkuat analisa data.

\section{B. HASIL DAN BAHASAN}

Rotan merupakan sumber daya yang melimpah di desa Talingke. Rotan tersebut bukan dihasilkan dari hasil hutan melainkan hasil budidaya di lahan milik masyarakat. Di desa Talingke hampir setiap keluarga memiliki paling tidak 1 lembar $^{6}$ kebun rotan di mana lahan rotan yang ada merupakan lahan yang dimiliki masyarakat secara turun temurun. Tidak heran jika mata pencaharian sebagai petani rotan juga merupakan mata pencaharian yang dilakukan secara turun temurun.

Secara historis, rotan memiliki peranan yang sangat besar terhadap kehidupan masyarakat di desa Talingke. Tidak sedikit warga yang merasakan kejayaan rotan pada masanya. Mulai dari bisa membangun rumah, menyekolahkan anak hingga ke jenjang sarjana, bahkan menabung dari hasil penjualan rotan. Seorang petani rotan, Fetiansyah( \pm 52 tahun) adalah satu dari beberapa petani rotan yang mengalami kejayaan rotan di masanya. Dari penuturannya di kurun waktu 1998-2002 dengan harga 1 pikul rotan \pm Rp 200 ribu, ia berhasil menabung sebesar 100 ribu per hari sehingga dapat menyekolahkan empat anaknya hingga ke jenjang sarjana.

KisahFetiansyah menjadi sepenggal cerita manis bagaimana rotan mampu menghidupi petani di Talingke. Namun dibalik cerita

6 Satu lembar kebun setara dengan 2 hektar. manis tersebut, terdapat kisah pahit bagaimana tata niaga rotan dikelola di tingkat desa. Sebagai mata pencaharian yang telah dilakukan secara turun temurun, perubahan dalam pengelolaan (terutama penjualan) rotan menjadi gambaran bagaimana petani rotan menghadapi situasi dan kondisi pasar tanpa dapat mengelak. Perubahan yang pertama dalam hal jenis produk yang dijual yaitu dari rotan kering menjadi rotan basah dan perubahan yang kedua yaitu dalam hal sistem penjualan. Dalam sistem penjualan rotan di Katingan khususnya di Talingke petani rotan berhadapan langsung dengan pengepul sebagai pihak yang menampung hasil rotan petani.

\section{Rotan yang Dijual : Dari Rotan Kering ke Rotan Basah}

Di tahun 1970 an, petani rotan di Talingke menjual rotan kepada para pengepul dalam kondisi kering. Rotan kering dihasilkan dari proses yang panjang dengan mengandalkan sinar matahari dalam proses pengeringannya. Proses pertama, rotan terlebih dahulu diambil dari kebun. Untuk memanen rotan sebanyak 1 pikul, dibutuhkan dua orang petani yang bekerja dalam waktu 2-3 hari. Dalam waktu seminggu dua orang petani bisa memeroleh 2-3 pikul rotan. Rotan yang telah dipanen kemudian dibawa ke desa dan direndam di sungai \pm 5 hari. Setelah direndam, rotan diangkat dari air dan diruntih ${ }^{7}$. Proses selanjutnya rotan yang telah diruntih, dijemur di bawah sinar matahari selama \pm 3 hari. Setelah kering, rotan akan diikat (mengeteng) dan baru ditimbang ketika pengepul ${ }^{8}$ datang ke desa.

Menjual rotan dalam kondisi kering ke pengepul menghasilkan harga yang lebih tinggi dibandingkan dengan menjual rotan basah. Satu pikul rotan kering dihasilkan

7 Runtih merupakan proses di mana batang rotan dibersihkan dengan menggunakan batu lenta (terbuat dari lingkaran kecil terbuat dari besi).

8 Pengepul sering disebut juga pengumpul. 
dari 3,5 pikul rotan basah. Jika diumpamakan harga rotan basah $\mathrm{Rp}$ 200.000/pikul ${ }^{9}$, maka 3.5 pikul rotan basah dihargai Rp 700.000. Dengan harga rotan kering $\mathrm{Rp} 800.000 /$ pikul maka terdapat selisih harga sebesar Rp 100.000. Selisih harga tersebut menjadi kelebihan harga yang diperoleh petani bila menjual rotan kering.

Dari rotan kering penjualan rotan kemudian berubah ke rotan basah. Adanya aturan penggunaan belerang dalam pengeringan rotan, menjadi faktor pendorong terjadinya perubahan tersebut. Di satu sisi, pengepul hanya mau membeli rotan basah milik warga dan kemudian mengeringkannya sendiri sebelum dikirim ke Banjarmasin. Di sisi lain, petani rotan juga enggan untuk mengeringkan rotan dengan belerang karena dalam proses ini dibutuhkan waktu yang lama, tenaga kerja yang cukup banyak, tempat yang luas dan jauh dari pemukiman, beresiko terhadap kesehatan serta biaya yang dinilai mahal. Seperti yang diungkapkan Pak Runjan :

\section{"Sekarang ini segala sesuatunya serba ingin yang cepat, dulu kita itu menge- ringkan rotan dengan panas matahari, kita jemur tu lah, sekarang mana ada, mau makan dengan apa kalau jemur dengan matahari, kalau belerang, resiko dia, batuk-batuk, mahal juga, akhirnya petani itu jual basah ja".}

Berbeda dengan rotan kering, proses pengumpulan rotan basah jauh lebih cepat. Setelah diambil dari kebun, rotan direndam di sungai dan baru diangkat untuk ditimbang saat pengepul datang untuk membeli rotan. Proses ini beresiko karena bila terlalu lama direndam, rotan menjadi rusak. Perendaman menjadi pilihan terbaik walaupun menyebabkan kualitas rotan turun. Perubahan dari rotan kering ke rotan basah menjadikan pengetahuan pengeringan

9 Satu pikul setara dengan satu kuintal. rotan secara alami tidak lagi dimiliki warga. Bahkan peralatan yang digunakan dalam pengeringan rotan tidak lagi dapat ditemukan di Talingke.

\section{Sistem Panjar dan Sistem Mandiri dalam Penjualan Rotan}

Sistem panjar telah banyak dikenal dalam transaksi jual beli. Panjar (n) berarti uang muka, persekot, cengkeram (Kamus Besar Bahasa Indonesia). Sistem panjar dalam penjualan rotan didefinisikan sebagai sistem di mana petani mendapatkan uang terlebih dahulu dari pemberi panjar sebagai modal awal dan rotan yang diperoleh menjadi hak milik pemberi modal. Uang panjar dapat dikatakan sebagai uang pengikat antara petani rotan dan pemberi panjar serta pemilik modal. Sistem panjar memungkinkan petani rotan memiliki memiliki uang untuk membeli minyak ces/ketinting dan sekaligus untuk membeli kebutuhan hidup sehari-hari. Di dalam sistem panjar ada tiga pihak yang terlibat yaitu petani rotan, pemberi panjar dan pemilik modal (pengepul).

Pemilik modal adalah pihak yang memiliki modal. Pemilik modal sering juga disebut dengan pengepul. Biasanya pemberi modal memiliki kapal yang akan berkeliling ke desa-desa setiap $10-15$ hari sekali untuk mengangkut rotan dari para petani yang bekerja dengan mereka. Di Talingke, pemberi modal biasanya bos-bos besar dari Kasongan/Katingan atau Sampit. Agar modal yang diberikan dapat dikelola dengan baik maka pemilik modal harus bisa memilih orang yang tepat untuk bertugas sebagai pemberi panjar di tingkat desa. Pemilihan pemberi panjar biasanya berdasar hubungan pertemanan dan kepercayaan.

Pemberi panjar adalah orang yang diberi kepercayaan pemilik modal untuk mengelola modal yang diberikan dengan cara mencari petani rotan yang mau bekerja (menjual rotan) kepada pemilik modal (pengepul). Pemberi panjar layaknya seorang perantara antara 
petani dan pengepul/pemilik modal. Dengan adanya pemberi panjar, seorang pemilik modal tidak perlu berurusan langsung dengan petani. Mereka yang menjadi pemberi panjar adalah orang desa setempat yang bertugas untuk memastikan para petani menyediakan rotan sesuai jumlah yang telah disepakati. Biasanya seorang pemberi panjar membawahi 10-15 petani rotan. Dengan bekerja sebagai orang kepercayaan pemilik modal, seorang pemberi panjar akan mendapatkan uang persen dari penjualan rotan yaitu selisih harga yang diterima petani dengan harga yang dibeli oleh pemilik/ pemberi modal. Misalnya rotan dibeli dari warga Rp 150.000 per pikul sedangkan harga dari pemilik modal Rp 170.000 per pikul maka pengumpul rotan mendapat keuntungan selisih kedua harga tersebut yaitu Rp 20.000 per pikul. Selisih harga yang diperoleh menjadi uang atas jasanya dalam mengumpulkan rotan dari petani. Bekerja sebagai pemberi panjar bukan tidak beresiko. Pemberi panjar harus bisa mencari orang atau petani rotan yang bertanggung jawab untuk memenuhi kewajiban menyediakan rotan sesuai yang telah disepakati ${ }^{10}$. Oleh karena itu biasanya pemberi panjar hanya bekerja sama dengan orang-orang yang telah dikenal sehingga bisa meminimalisir kerugian. Selain itu meski bertindak selaku pemberi panjar, namun tidak menutup kemungkinan bagi pemberi panjar untuk ikut menyediakan rotan bagi pemilik modal sehingga ia juga bisa memeroleh uang dari penjualan rotan.

Petani rotan adalah pihak penyedia rotan. Rotan yang diperoleh petani bisa diambil dari lahan sendiri maupun dipanen dari lahan orang lain. Jika dari lahan sendiri maka seluruh rotan yang dijual menjadi milik diri sendiri sedangkan jika memanen rotan di kebun orang lain hasil penjualan

10 Jika petani rotan tidak bisa menyediakan rotan sesuai jumlah yang disepakati di waktu yang telah ditentukan maka petani tetap memiliki kewajiban untuk memenuhi jumlah sesuai yang disepakati. rotan akan dibagi dengan pemilik kebun. Sebagai contoh apabila mendapat 10 pikul maka 4,5 pikul untuk pemilik kebun dan 4,5 pikul untuk pekerja serta 1 pikul untuk pekerja atau seorang petani rotan mendapatkan 9 bagian $x 1 / 2$ harga jual dan 1 bagian harga jual penuh. Sebagai penyedia rotan, petani wajib menyediakan rotan hanya kepada pemberi panjar atau pemilik modal yang telah memberikan panjar.

Dalam sistem panjar pada sistem penjualan rotan terlihat resiprositas antara ketiga belah pihak. Resiprositas umum adalah cara tukar menukar di mana yang memberi maupun yang menerima menentukan dengan pasti nilai barang yang terlibat dan waktu penyerahannya (Haviland, 1993:51). Pada sistem penjualan rotan di desa, hubungan antara petani rotan - pemberi panjar pemilik modal/pengepul terjalin karena adanya kesepakatan. Pemilik modal dan pemberi panjar menentukan harga dan jika sepakat dengan harga yang ditentukan maka petani rotan akan menjual rotannya kepada pemilik modal/pengepul melalui pemberi panjar. Dalam prakteknya, resiprositas yang terjalin tidaklah seimbang. Pemberi panjar dan pemilik modal dalam hal ini memiliki dominasi dalam hal penentuan harga komoditas yang diperjualbelikan (rotan). Hubungan ketiga pihak ini berdasarkan pada rasa percaya. Jika petani tidak dapat memenuhi kewajibannya di waktu yang telah disepakati, maka ia tetap akan melunasi kewajibannya terhadap pemilik modal dilain waktu. Hubungan ketiga pihak ini dapat berakhir jika salah satu pihak merasa tidak diuntungkan. Petani rotan memiliki pilihan untuk tidak menjual rotannya apabila harga dinilai tidak sebanding dengan usaha yang dikeluarkan dan menghentikan hubungan dengan pemberi panjar/pemilik modal setelah ia menyelesaikan kewajibannya. Sementara pemilik modal tetap hanya akan mengambil rotan dari petani yang bersedia 
menjual rotan sesuai harga yang telah ditentukan.

Selain memperlihatkan resiprosi-tas, tata niaga rotan di desa juga menunjukan adanya hubungan patron klien. Hubungan patron klien dinyatakan sebagai kasus khusus dari ikatan diadik (dua orang) yang terutama melibatkan persahabatan instrumental di mana seorang individu dengan status sosio - ekonomi yang lebih tinggi (patron) menggunakan pengaruh dan sumber dayanya untuk menyediakan perlindungan dan atau keuntungan-keuntungan bagi seseorang dengan status lebih rendah (klien) (Scott,1993:7). Dalam tata niaga rotan di desa, pemilik modal atau pengepul adalah patron bagi petani rotan yang merupakan kliennya. Pemilik modal menyediakan modal kerja bagi petani dan sekaligus memberikan jaminan terpenuhinya kebutuhan hidup melalui uang panjar yang diberikan. Arus patron ke klien salah satunya adalah memberikan jaminan subsistensi bagi kliennya dengan menyerap kerugian-kerugian yang akan merusak kehidupan klien jika tidak dilakukan oleh patron (Scott, 1993:9-14). Sedangkan bagi klien tujuan dasar dari kontrak patronklien adalah penyediaan jaminan social dasar bagi subsistensi dan keamanan. Petani rotan memeroleh kepastian rotan terjual sehingga mengurangi resiko kerusakan rotan akibat direndam di sungai. Petani rotan juga mendapatkan modal kerja serta jaminan hidup selama mencari rotan melalui uang panjar yang diberikan. Di sisi lain bagi pemilik modal maupun pemberi panjar mereka bisa mendapatkan keuntungan dari harga jual-beli rotan serta kepastian untuk mendapatkan rotan. Mayoritas petani rotan di desa Talingke menilai menjual rotan dengan sistem panjar jauh lebih menguntungkan dibandingkan menjual rotan secara mandiri. Oleh karena itu relasi patron-klien juga dapat dipandang sebagai salah satu upaya manusia untuk dapat bertahan hidup dalam situasi tertentu (Ahimsa, 1988: 23).
Sistem penjualan dengan menggunakan sistem panjar baru muncul beberapa tahun terakhir. Sistem ini menggantikan sistem penjualan mandiri yang dilakukan oleh petani. Sistem mandiri didefinisikan dengan bekerja secara mandiri sehingga tidak terikat hubungan dengan pihak lain. Dalam hal ini petani rotan bekerja untuk dirinya sendiri dengan modal yang dimilikinya dan bekerja sesuai dengan kemauan dan kemampuannya.

Sistem mandiri mengharuskan petani rotan memiliki modal untuk bekerja dan jaminan hidup. Modal untuk bekerja digunakan untuk membeli bahan bakar ces $^{11}$ yang digunakan sebagai transportasi menuju kebun $\operatorname{rotan}^{12}$. Modal kerja ini sebenarnya tidak terlalu banyak dibandingkan dengan jaminan hidup yang harus disediakan oleh petani. Jaminan hidup tersebut adalah ketersediaan uang untuk membeli kebutuhan sehari-hari hingga rotan terjual. Dengan sistem mandiri, jika rotan tidak segera terjual, para petani rotan mensiasati hal tersebut dengan mengambil beras atau kebutuhan di warung ${ }^{13}$ (berhutang) dan membayarnya ketika rotan telah terjual.

Bekerja dengan system mandiri juga berarti petani tidak memiliki ikatan dengan pembeli rotan. Hal ini beresiko tinggi. Bila rotan tidak segera terjual, rotan akan lama terendam di sungai sehingga beresiko merusak kualitas rotan. Saat ini tidak banyak petani yang menggunakan system mandiri karena besarnya resiko yang dihadapi dan

11 Ces adalah kapal motor tempel yang terbuat dari kayu dengan panjang bervariasi dengan lebar 1 meter. Pada bagian belakang ces dipasang mesin tempel (5-10 PK) yang bisa dibongkar pasang. Ces merupakan transportasi harian penduduk yang tinggal di pinggir sungai untuk beraktifitas (ke ladang, memancing/menjala ikan dan lainlain).

12 Hampir semua lokasi kebun rotan hanya bisa diakses melalui jalan air (sungai) dengan menggunakan ces atau ketinting.

13 Petani rotan biasanya akan berhutang di warung tetangga yang cukup dekat atau warung milik saudara karena tidak semua warung bersedia memberikan pinjaman. Hutang akan dibayar setelah petani rotan mendapatkan uang. Oleh karena itu penting untuk membangun hubungan dengan dasar saling percaya. 
besarnya modal yang harus dimiliki. Oleh karena itu mayoritas petani rotan di Talingke banyak beralih bekerja dengan sistem panjar. Namun meski demikian, beberapa petani rotan masih ada yang memilih bekerja secara mandiri.

"Kalau saya pribadi sih tidak mau menggunakan sistem panjar itu, saya pikir kalau saya waktu sakit, saya ga mau pikir, karena saya punya utang, bisa jak nanti kada sembuh-sembuh, banyak pikiran lok", ungkap Pak Yasmi, seorang petani rotan berusia 40an tahun.

Senada dengan pak Yasmi,

“Saya ndak pakai itu (sistem panjar) takut nanti kalau tidak terbayar to.Ya kalau dapat rotannya. Kalau ndak dapat, malah hutang nanti. Ndak enak to", jelas Pak Tikno, pendatang dari Jawa yang telah bekerja sejak tahun 1970 an sebagai petani rotan di Talingke.

Ikatan yang terjalin dalam sistem panjar menjadi pertimbangan bagi Pak Tikno dan Pak Yasmi untuk tetap bekerja secara mandiri. Kondisi kesehatan dan cuaca yang tidak menentu ${ }^{14}$ menjadi faktor yang bisa memengaruhi mereka dalam memeroleh rotan. Jika tidak bisa memenuhi jumlah rotan yang disepakati maka hal itu berarti mereka memiliki hutang. Kekhawatiran akan memiliki hutang inilah yang membuat pak Yasmi dan Pak Tikno lebih memilih untuk tetap bekerja secara mandiri

\section{Fluktuasi Harga dan Strategi Adaptasi Petani}

Sebagai penyedia rotan, petani rotan selalu dihadapkan pada mekanisme harga yang telah ditentukan oleh pemilik modal. Baik dalam sistem panjar maupun bekerja secara mandiri, petani rotan harus tunduk

14 Musim hujan menjadikan lahan rotan tergenang sehingga menyulitkan petani yang akan memanen rotan. dengan harga yang telah ditetapkan oleh pembeli rotan /pemilik modal. Panjangnya alur distribusi rotan menjadi salah satu faktor rendahnya harga yang diberikan kepada petani. Berikut alur distribusi rotan dari tingkat kecamatan :

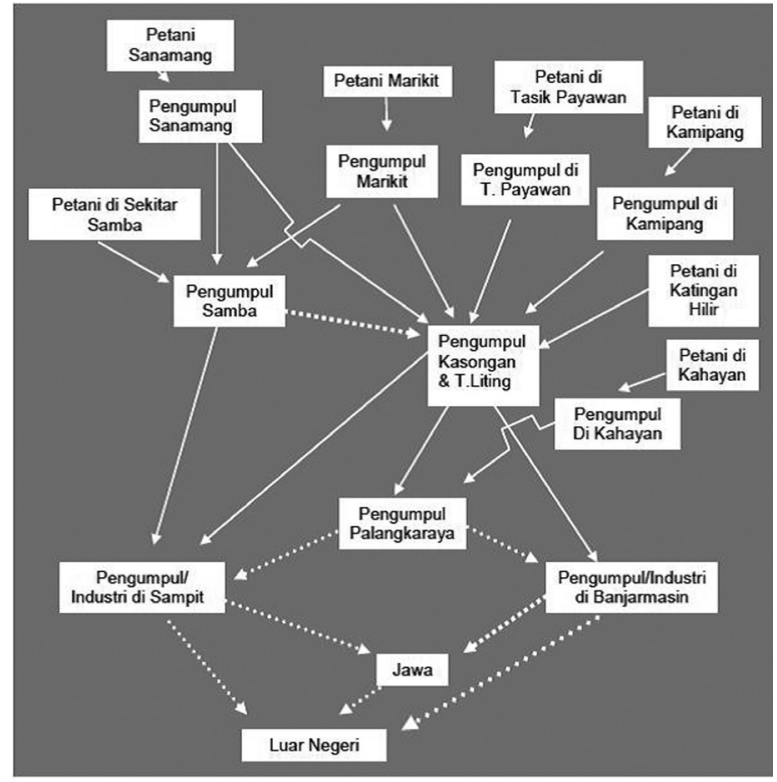

Gambar 1. Alur Distribusi Bahan Baku dari tingkat kecamatan di Katingan

Sumber : Yayasan Teropong dan Yayasan SHK di tahun 2005 (Sumardjani, 2011:30).

Sedangkan dalam pengetahuan petani rotan di desa, alur tata niaga adalah sebagai berikut :

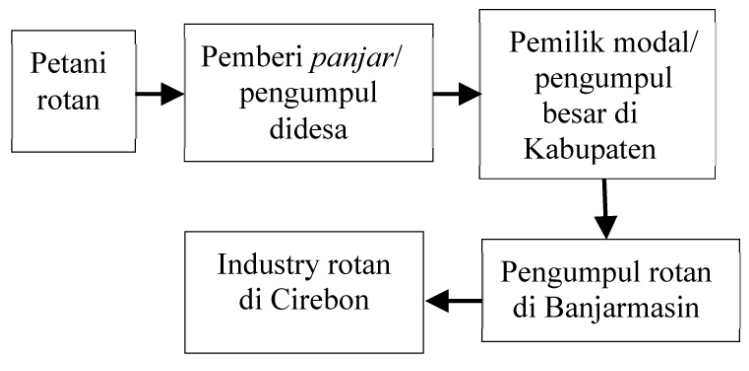

Gambar 2. Alur tata niaga menurut petani di desa Talingke.

Sebagai penyedia bahan baku, petani rotan hanya mengetahui bahwa rotan yang ditanam akan di bawa ke Banjarmasin sebelum dikirim ke Cirebon. Padahal jika merujuk pada alur distribusi rotan pada gambar 1, alur distribusi rotan harus melalui beberapa pihak dan melalui pemrosesan 
sebelum menjadi bahan baku kerajinan rotan. Untuk memberikan gambaran mengenai harga rotan dari tingkat petani hingga industry, bisa dilihat dalam skema perdagangan rotan tahun 2004-2005 berikut ini :
Pola 1

Pola 2

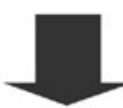

Petani
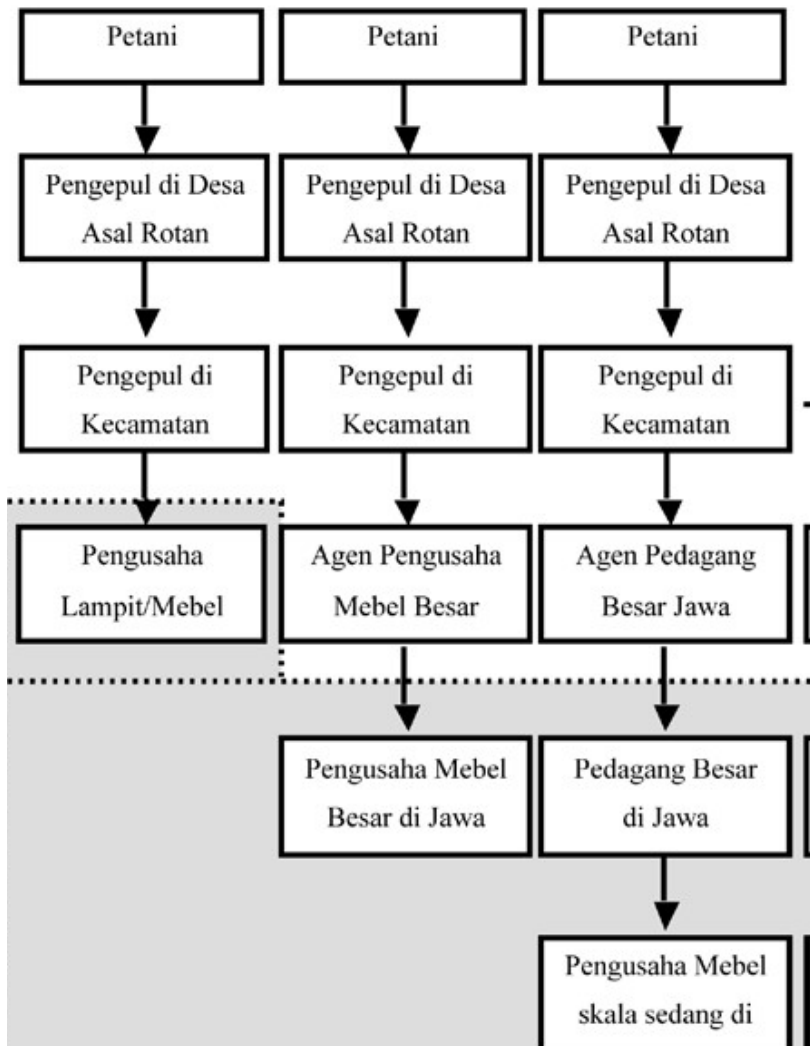

Pola 3

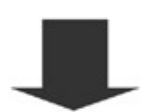

Petani

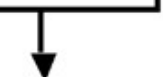

Pengepul di Desa Asal Rotan
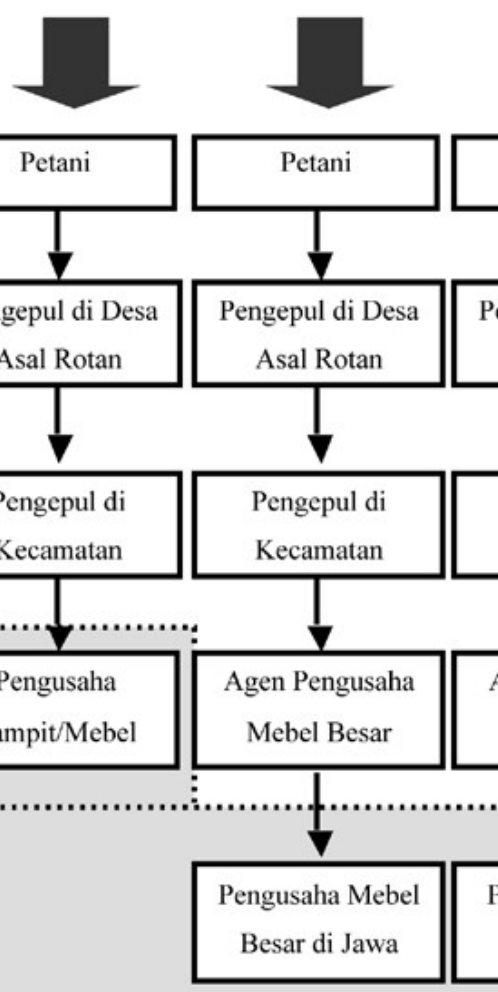

$\underline{\text { Pola } 4}$

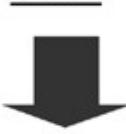

Petani

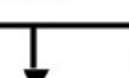

Rp $2000-2500$

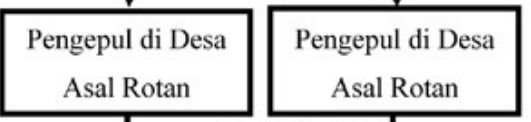

$\operatorname{Rp} 3000-3500$
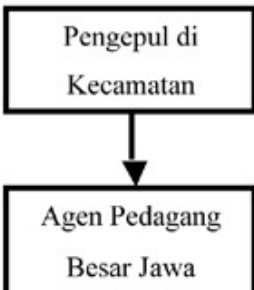

$\underline{\text { Pola } 5}$

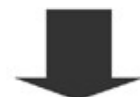

etani

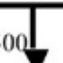

engepul di

Kecamatan

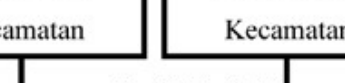

Rp 4000 - 4500
Pedagang Antar
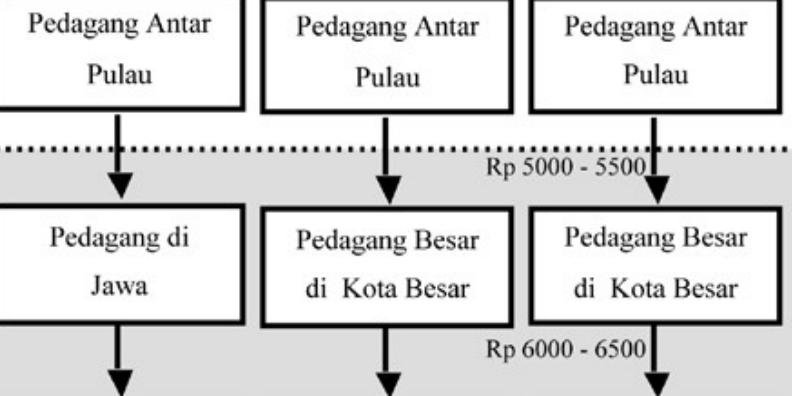

Pengusaha Mebel skala sedang di Jawa

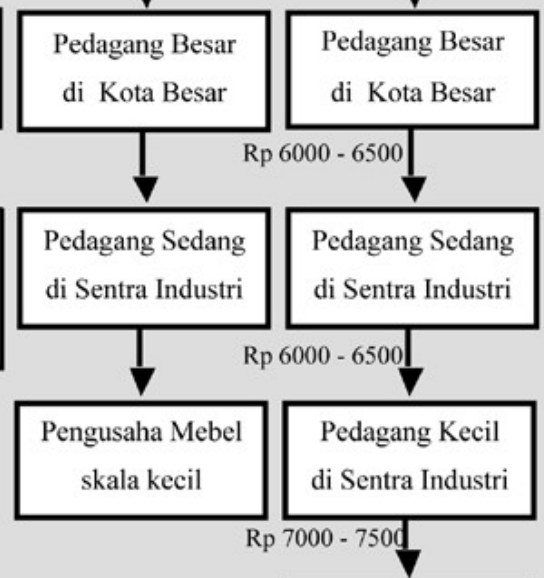

Catatan: Harga yang tercantum mengambil contoh harga untuk Sega $4-8 \mathrm{~mm}$ asalan atau Kubusof $4-8 \mathrm{~mm}$ asalan.
Dalam skema tersebut terlihat bagaimana perubahan harga rotan dari satu jenjang ke jenjang berikutnya. Sebagai contoh untuk bisa menjadi lampit, rotan harus melalui 4 jenjang penjualan di mana rotan yang awalnya seharga $R p 2.000$ - Rp 2.500 per kg berubah menjadi Rp 5.000 - 5.500. Harga tersebut akan terus naik pada jenjang ber- ikutnya dan di tingkat akhir mencapai 3 kali lipat dari harga di tingkat petani (Sumardjani, 2011:30).

Selain panjangnya alur distribusi, kebijakan pemerintah juga berpengaruh terhadap harga rotan di tingkat petani. Salah satu kebijakan pemerintah yang dinilai masyarakat sebagai penyebab turunnya harga 
rotan adalah adanya pembatasan ekspor rotan mentah di tahun $2011^{15}$.

Pahit manis pengelolaan rotan telah menjadi "makanan" para petani dari waktu ke waktu. Di era tahun 1970 an harga 1 pikul rotan kering mencapai Rp150.000 Rp 170.000 jauh lebih tinggi dibandingkan dengan harga kebutuhan hidup seharihari ${ }^{16}$. Sekitar tahun 1986-1989 harga jual rotan kering mencapai 160.000/pikul untuk rotan Irit, dengan harga beras 1 kiloRp 2.500. Di tahun 90 an - awal hingga tahun 2000 an harga rotan kering mencapai Rp 800.000 per pikul dan harga rotan basah $\mathrm{Rp}$ 200.000. Harga ini kembali naik di tahun 2006 di mana harga rotan mencapai Rp 220.000 per kuintal untuk rotan Irit. Bagi warga harga ini cukup tinggi mengingat harga kebutuhan rumah tangga masih jauh di bawah harga tersebut. Bahkan para petani dapat menyisihkan uang sebagai tabungan dari penghasilan rotan. Setelah tahun 2006, harga rotan mengalami penurunan hingga menjadi Rp 120.000 per kuintal untuk rotan Irit dan Rp 150.000 per kuintal untuk rotan Sigi. Tahun 2011 - 2013 menjadi titik akhir bagi petani rotan di Talingke. Dengan harga Rp 80.000 per kuintal untuk rotan Irit tidak ada lagi petani rotan di Talingke yang mau memanen rotannya. Harga rotan Rp 80.000/ pikul dinilai tidak lagi seimbang dengan harga kebutuhan pokok sehari-hari bahkan tidak cukup untuk membeli sekarung beras.

"1 pikul rotan itu dapatnya 2 hari, dan saat ini nilai tersebut hanya berkisar antara 80.000-90.000 untuk Irit. Itu 2 hari baru dapat uang dia, itu juga 80.000, baru yang hari sebelumnya mau makan pakai apa?",kata Pak Santri
Keengganan petani rotan untuk memanen rotan berdampak pada ketersediaan rotan dikebun. Jika terlalu lama tidak dipanen, maka rotan ${ }^{17} a k a n$ mati dan tentu hal ini menjadi kerugian tersendiri bagi petani. Pada akhirnya petani seperti dihadapkan pada dua pilihan yang sama-sama tidak menguntungkan yaitu membiarkan tanaman rotan tetap di kebun dan mati atau memanen rotan dengan harga yang tidak sebanding dengan harga kebutuhan hidup. Dari dua pilihan tersebut, membiarkan rotan tetap berada di kebun menjadi pilihan akhir petani rotan Talingke.

Dari uraian tersebut terlihat bagaimana fluktuasi harga rotan terjadi dari waktu ke waktu dan mengalami titik terendah pada beberapa tahun terakhir ini. Harga rotan yang terkadang dinilai tidak sesuai dengan kebutuhan mendorong petani rotan untuk selalu memiliki mata pencaharian lain sebagai bentuk strategi adaptasi petani terhadap kondisi yang terjadi. Strategi adaptasi menurut Bennet dalam Kutanagara (2014 : 27) adalah tindakan-tindakan strategis yang didasarkan pertimbangan khusus dengan pertimbangan sesuai kemampuan dan dapat diperkirakan tingkat keberhasilannya. Memanfaatkan sumber daya alam di lingkungan sekitar sebagai alternatif penghasilan merupakan tindakan strategis yang dilakukan petani Talingke dalam menghadapi fluktuasi harga. Pemanfaatan sumber daya alam ini memperlihatkan adanya interaksi antara manusia dengan lingkungannya seperti yang dikatakan oleh Haviland bahwa interaksi antara manusia dengan lingkungannya terlihat dari bagaimana manusia mengerjakan, mengelola serta memanfaatkan sumber daya yang ditemukan di lingkungan tempat tinggalnya (Havilland 1993: 3). Kayu di

\footnotetext{
17 Petani rotan di Talingke selama ini membudidayakan jenis rotan Irit. Jenis ini dibudidayakan karena mudah tumbuh. Berselang 6 bulan setelah dipanen, rotan dapat dipanen lagi. Membiarkan rotan tidak dipanen beresiko menjadikan rotan mati.
}

\footnotetext{
15 Pembatasan ekspor rotan mentah tertuang dalam Permendag No.35 tahun 2011 tentang ketentuan ekspo rotan dan produk rotan. Dalam peraturan tersebut bahwa larangan ekspor berlaku untuk rotan 161 sak beras Rp 7.000, lauk melimpah di sungai.
} 
hutan ${ }^{18}$, ikan di sungai ${ }^{19}$ atau karet di kebun menjadi sumber penghasilan lain selain rotan. Mata pencaharian ini selalu dilakukan di saat harga rotan turun atau saat kondisi cuaca tidak mendukung petani rotan memanen rotan.

Di antara seluruh sumber daya yang ada di Talingke, karet juga menjadi andalan para petani di Talingke sebagai sumber penghasilan penting. Namun sama dengan rotan, harga karet tidak kunjung membaik beberapa tahun terakhir yaitu di kisaran Rp 4000 - 5000/kg. Dengan kondisi ini, petani di Talingke akhirnya memanfaatkan sungai sebagai sumber penghasilan yaitu dengan menjadi penambang emas. Aktivitas penambangan emas yang dimulai sejak tahun 2011 dan marak di tahun 2013-2014 ini dinilai sebagai satu-satunya alternative mata pencaharian yang mampu menjadi tumpuan hidup para petani rotan. Hampir seluruh petani $\operatorname{rotan}^{20}$ pada akhirnya beralih menjadi penambang emas sebagai strategi untuk terus bertahan.

Rendahnya harga rotan - dan karet memberikan efek domino pada kehidupan petani rotan. Para petani tidak hanya kehilangan mata pencaharian namun kondisi ini mengancam eksistensi kebun-kebun rotan di Talingke. Aktivitas pertambangan emas yang semula berlokasi di sungai, kini mulai menyasar lokasi di darat yaitu kebun-kebun

18 Mata pencaharian sebagai pencari kayu pernah dilakukan warga pada kurun waktu 1970 an - 2004 yaitu dengan bekerja di perusahaan-perusahaan kayu. Di tahun 1970 an kayu ramin menjadi hasil hutan yang paling banyak dicari karena menjadi produk ekspor ke Jepang. Mata pencaharian dengan mengandalkan kayu di hutan berhenti sejak tahun 2004 bersamaan dengan semakin ketatnya aturan logging.

19 Selama ini Desa Talingke dikenal dengan komoditas unggulan berupa rotan dan ikan segar. Selain posisi desa yang berada di tepi Sungai Katingan, desa ini juga memiliki 6 buah danau serta anak sungai yang merupakan sumber ikan segar. Menggaul lauk (mencari ikan) dilakukan dengan memancing atau menangkap ikan di sungai dengan jala baik untuk konsumsi harian maupun dijual sebagai sumber penghasilan.

20 Petani rotan perempuan dan laki-laki yang telah berusia lanjut (diatas 55 tahun) tidak bisa bekerja dipertambangan emas karena bekerja sebagai penambang emas dirasakan jauh lebih berat dan membutuhkan tenaga yang besar. rotan. Hasil emas di sungai yang semakin berkurang menjadikan para penambang emas memanfaatkan kebun rotan sebagai lokasi penambangan dengan asumsi terdapat kandungan emas di dalam tanah. Aktivitas ini tentu mengancam kelestarian lingkungan di Talingke terutama kebunkebun agroforestry ${ }^{21}$ warga.

\section{Rotan Masih Diharapkan}

Rendahnya harga rotan mem-bawa perubahan pada aktivitas niaga rotan di sungai Katingan. Kapal milik pengepul yang biasa hilir mudik di sungai Katingan mengambil rotan dari petani tidak lagi banyak terlihat. Para petani rotan yang saat ini bekerja sebagai penambang emas masih mengharapkan aktivitas niaga rotan kembali lagi seperti sediakala. Besarnya potensi rotan di kebunkebun warga masih membuka peluang bagi hidupnya tata niaga rotan di desa.

"Jika ingin kerja rotan lagi setidaknya harga jualnya harus seimbang dengan kebutuhan sehari-hari, sekarang itu harga rotan dapat dikatakan seimbang kalau dia harganya sampai 140.000, per pikul ya, itu basah dan Irit lho baru mau saya kerja rotan lagi", papar Pak Tikno

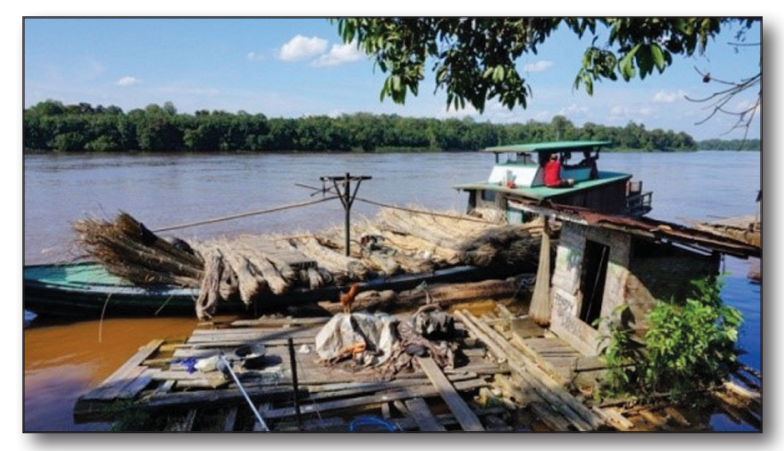

Gambar 4. Selama 2 minggu hanya ada 1 kapal dari Sampit yang masih mengambil rotan dari desa-desa di hilir Sungai Katingan.

Sumber : Dokumentasi penulis, desa Talingke, 2016.

21 Diakses dari www.worldagroforestry.org, agroforestry merupakan sistem penggunaan lahan (usaha tani) yang mengkombinasikan pepohonan dengan tanaman pertanian untuk meningkatkan keuntungan, baik secara ekonomis maupun lingkungan. 
Bagi warga Talingke, menjadi petani rotan merupakan mata pencaharian yang tetap ingin ditekuni sebagai sumber penghasilan. Hal ini disebabkan rotan dinilai lebih "nyata dan pasti" sedangkan emas merupakan sumber daya yang "tidak nyata dan tidak pasti". Berbeda dengan emas yang tidak nyata (tidak terlihat, ada didalam tanah/sungai) dan belum tentu dapat ditemukan (tidak pasti), rotan adalah sumber daya yang "nyata" (dapat dilihat) dan "pasti" (ada di kebun warga).

Kenaikan harga rotan menjadi harapan para petani agar tetap dapat mendapatkan sumber penghasilan dari rotan. Rata-rata para petani berharap harga rotan berada dikisaran 150.000/pikul untuk rotan Irit dan 200.000/pikul untuk rotan Sigi. Harga tersebut terbilang pantas karena dinilai dapat memenuhi kebutuhan sehari-hari atau seimbang dengan harga sembako.

\section{PENUTUP}

Sistem penjualan rotan di desa dapat dilihat dari jenis rotan yang dijual dan cara petani menjual rotan. Jenis rotan yang dijual oleh petani rotan di Talingke mengalami perubahan dari menjual rotan kering ke rotan basah. Perubahan ini disebabkan karena pengepul atau pembeli hanya mau membeli rotan basah dari petani. Dalam hal cara penjualan, petani rotan dapat menggunakan penjualan dengan sistem mandiri dan sistem panjar. Dalam kedua sistem tersebut, masingmasing pihak saling memberi dan menerima sesuai dengan yang telah disepakati. Khusus dalam sistem panjar, jaminan keamanan dan ketersediaan modal menggambarkan terjadinya hubungan resiprositas. Meski dalam prakteknya terjadi dominasi dari pihak yang lebih berkuasa (pemilik modal) namun petani rotan tetap memiliki strategi menghadapi dominasi tersebut. Fluktuasi harga dihadapi dengan cara memiliki alternatif mata pencaharian lain seperti mencari kayu di hutan, menjadi nelayan atau mata pencaharian yang kini sedang marak di desa yaitu sebagai penambang emas.

Kehidupan petani rotan akan terus menghadapi ketidakpastian akibat dari harga pasar yang terus berubah. Di pasar rotan, keberadaan rotan alam terancam dengan adanya rotan plastik sebagai bahan furniture. Dibutuhkan kebijakan yang tepat dan tidak hanya menguntungkan industri pengolahan rotan di hilir namun yang paling penting juga memperhatikan kondisi di hulu. Kebijakan untuk menaikkan dan menjaga kestabilan harga akan menjadi pendorong warga untuk kembali ke rotan sebagai sumber penghasilan sehingga tekanan terhadap lingkungan (dengan adanya penambangan emas) semakin berkurang. Sebagai sumber daya yang melimpah rotan masih sangat berpotensi untuk dikembangkan dan diandalkan sebagai sumber penghidupan masyarakat. Dari sisi lingkungan, kebun rotan dapat menjaga ekosistem hutan dan mencegah erosi tanah oleh air sungai. Oleh karena itu sebagai sumber daya yang ramah lingkungan dan dapat dimanfaatkan sebagai sumber penghasilan sudah sepantasnya rotan mendapatkan perhatian lebih dari pemerintah melalui kebijakan yang tepat terutama bagi petani rotan.

\section{DAFTAR SUMBER}

Ahimsa Putra, Heddy. 1988. Minawang Hubungan Patron - Klien di Sulawesi Selatan. Yogyakarta: Gadjah Mada University Press.

Anonim. 2012. Kerajinan Rotan, diunduh dari www.disparbud.jabarprov.go.id pada 10 September 2017.

Erviyani, Makkarennu, Muhammad Alif K.Sahide, Asar Said Mahbub. 2017. Analisis Tata Niaga Rotan di Kelurahan Batu Kecamatan Pitu Riase Kabupaten Sidenreng Rappang. 
Jurnal Hutan dan Masyarakat. Vol. 9 (1), hlm. 1-7.

Havilland, W. A. 1993. Antropologi, jilid 2 (edisi keempat), Jakarta : Penerbit Erlangga.

Hidayat, Asep dkk. 2006. Analisis Pemungutan Rotan pada Dua Kelompok Masyarakat Pemungut. Jurnal Penelitian Sosial dan Ekonomi Kehutanan. Volume 3 no 2.

Jalan Unggul Rotan Katingan, di unduh dari http://kpshk.org/ pada 15 Maret 2016.

Johanna Maria Rotinsulu, Sosilawaty, dan Yanarita. 2015. Agroforestry Berbasis Rotan Tehadap Sosial Ekonomi Masyarakat di Barito Selatan. Jurnal Hutan Tropis Volume 4 No. 1.

Kutanagara, Pande Made. 2014. Manusia, Lingkungan dan Sungai : Transformasi Sosial Kehidupan Masyarakat Sempadan Sungai Code. Yogyakarta : Ombak.

Moleong, Lexy J. 1996. Metodologi Penelitian Kualitatif. Bandung : Penerbit Remaja Rosdakarya.

Pribadi, Hendra. 2012. Kajian Ekonomi Pengembangan Usaha Industri Mebel Rotan di Kota Palu Provinsi Sulawesi Tengah. Jurnal Hutan Tropis Volume 13 No. 2 September 2012.

Rawing, Duwel. Potensi Produksi dan Pengembangan Rotan serta Permasalahannya di Kabupaten Katingan, diunduh dari storage.jak-stik.ac.id, pada 15 Maret 2016.

Rujiter, J dan F. Agus. Leaflet Agroforestry. April 2004, diunduh dari www. worldagroforestry.org/sea/ Publications/files/leaflet/LE0022-04. pdf diunduh pada 7 September 2017.

Ridho Witono, Joko, Himmah Rustiami, Julisasi Tri Hadiah, Danang Wahyu Purnomo. 2013. Panduan Lapangan Pengenalan Jenis Rotan Katingan. Palangka Raya : WWF - Indonesia Program Kalimantan Tengah.

Scott, James. C. 1993. Perlawanan Kaum Tani. Jakarta : Yayasan Obor Indonesia

Sugiyono. 2009. Metode Penelitian Kuantitatif, Kualitatif dan RED. Bandung: Penerbit Alfabeta.

Sumardjani, Lisman. 2011. Studi Rotan di Katingan Kalimantan Tengah.Palangka Raya: Yayasan Rotan Indonesia.

Susilawati. 2014. Kajian Posisi Tawar UD. Mandiri Rotan dalam Struktur Pasar Industri Rotan (Calamus spp) di Wilayah Kabupaten Banjar dan Kota Banjarbaru Provinsi Kalimantan Selatan. Enviroscienteae. Volume 1 no 1.

Wahyuno, Nanang Dwi. 2013. Kajian Produksi dan Pasar Komoditas Rotan di Jawa Timur. Inovasi. Vol. 13 No.3 Hal. 269-274, SeptemberDesember 2013.

Wawancara. Runjan. Desa Talingke, 16 Maret 2016.

Wawancara. Santri. Desa Talingke, 17 Maret 2016.

Wawancara. Tikno. Desa Talingke, 18 Maret 2016.

Wawancara.Yasmi. Desa Talingke, 20 Maret 2016. 